\title{
Availability and Structure of Coarse Woody Debris in Hemiboreal Mature to Old-Growth Aspen Stands and Its Implications for Forest Carbon Pool
}

\author{
Silva Šēnhofa ${ }^{1}\left(\mathbb{D}\right.$, Guntars Šṇepsts ${ }^{1}$, Kārlis Bičkovskis ${ }^{1}$, Ieva Jaunslaviete ${ }^{1}$, Līga Liepa ${ }^{2}$, Inga Straupe ${ }^{2}$ (I) \\ and Āris Jansons ${ }^{1, *(1 D}$ \\ 1 Latvian State Forest Research Institute Silava, Rigas Street 111, LV-2169 Salaspils, Latvia; \\ silva.senhofa@silava.lv (S.Š.); guntars.snepsts@silava.lv (G.Š.); karlis.bickovskis@silava.lv (K.B.); \\ ieva.jaunslaviete@silava.lv (I.J.) \\ 2 Forest Faculty, Latvia University of Life Sciences and Technologies, Liela Street 2, LV-3001 Jelgava, Latvia; \\ liga.liepa@llu.lv (L.L.); inga.straupe@llu.lv (I.S.) \\ * Correspondence: aris.jansons@silava.lv; Tel.: +371-291-095-29
}

check for updates

Citation: Šēnhofa, S.; Šnepsts, G.; Bičkovskis, K.; Jaunslaviete, I.; Liepa, L.; Straupe, I.; Jansons, Â. Availability and Structure of Coarse Woody Debris in Hemiboreal Mature to Old-Growth Aspen Stands and Its Implications for Forest Carbon Pool. Forests 2021, 12, 901. https://doi.org/ $10.3390 / \mathfrak{f} 12070901$

Received: 8 June 2021

Accepted: 9 July 2021

Published: 11 July 2021

Publisher's Note: MDPI stays neutral with regard to jurisdictional claims in published maps and institutional affiliations.

Copyright: (c) 2021 by the authors. Licensee MDPI, Basel, Switzerland. This article is an open access article distributed under the terms and conditions of the Creative Commons Attribution (CC BY) license (https:/ / creativecommons.org/licenses/by/ $4.0 /)$.

\begin{abstract}
European aspen deadwood is extensively studied as a habitat for saproxylic species, while less is known of its dynamics and role in carbon sequestration. We studied unmanaged mature (41-60 years), moderately overmature (61-80 years), overmature (81-100 years), and oldgrowth (101-140 years) and managed mature and moderately overmature aspen stands on fertile mineral soils. In unmanaged stands, marginal mean CWD volume was from $67.3 \pm 12.1 \mathrm{~m}^{3} \mathrm{ha}^{-1}$ in moderately overmature to $92.4 \pm 5.1 \mathrm{~m}^{3} \mathrm{ha}^{-1}$ in old-growth stands, with corresponding marginal mean CWD carbon pool $8.2 \pm 1.6 \mathrm{tha}^{-1}$ and $12.5 \pm 0.7 \mathrm{t} \mathrm{ha}^{-1}$ (all $p>0.05$ ), respectively. High CWD volume was present in most stands, by at least two-thirds of plots comprising more than $20 \mathrm{~m}^{3} \mathrm{ha}^{-1}$, and about half of CWD was larger than $30 \mathrm{~cm}$ in diameter. Changes in CWD species composition toward a higher proportion of deciduous deadwood in old-growth stands, together with a high volume of recently dead trees, suggest early senescence of the dominant aspen cohort.
\end{abstract}

Keywords: aspen senescence; carbon pool; deadwood; decline; overmature; Populus tremula

\section{Introduction}

European aspen (Populus tremula L.) is an early-succession species in boreal and hemiboreal forests [1], with scattered occurrence [2-4] but high ecological importance. Aspen is commonly regarded as 'keystone species' in the boreal and hemiboreal forests because both living and dead aspen trees host more specialist and endangered species than other tree species in the region [4-7]. Information of aspen deadwood volume and characteristics, however, is limited, with only some insights from studies in boreal [6,8-11] and hemiboreal [12] forests.

Besides the maintenance of biodiversity $[13,14]$, deadwood has an important role in carbon dynamics [15], estimated to comprise $8 \%$ of the total carbon pool in forests globally [16]. The deadwood persistence and turnover are affected by a number of factors, including disturbance dynamics, forest zone, site type and soil moisture regime, dominant species, stand age, and productivity [17-19]. Large knowledge gaps on the effect of the abovementioned factors on carbon pools remain and are substituted by internationally accepted standards. Latest studies show that even seemingly small improvement by empirical-based variables has a substantial effect on estimated global carbon stock [20]. Currently, the majority of knowledge on forest carbon pools is derived from studies performed in managed forests. The vast deadwood diversity in unmanaged, old-growth forests, however, hampers accurate estimations of carbon storage within it and has derived contrasting results on whether old-growth forests are a carbon sink or source [21-28]. While few studies have addressed the carbon budget in hemiboreal deciduous forests [29-32], 
including one in the old-growth forests [33], none have been performed in aspen-dominated stands. However, studies of stands older than the longevity of the pioneer cohort are emphasized as critical to improve the understanding of old forests in the global carbon cycle [34]. Knowledge of carbon balance in stands dominated by relatively short-lived species and how this balance changes with stand age is necessary in order to improve the accuracy of greenhouse gas emission and carbon sequestration models.

We aimed to quantify the availability of coarse woody debris (CWD) and its carbon pool and to characterize CWD structure in hemiboreal aspen stands. We intended to represent CWD and its carbon pool regarding species composition, pose, diameter, and decay classes with regard to its variation along with stand age from maturity to old-growth state.

\section{Materials and Methods}

This study was conducted in European aspen (Populus tremula L.) stands in hemiboreal forests (based on European Forest Types [35]) in Latvia. According to Latvian National Forest Inventory (NFI, 2014-2018), forests cover 52\% of the land. Aspen is the fourth most common tree species, following Scots pine (Pinus sylvestris L.), silver and downy birch (pooled Betula pendula Roth and Betula pubescens Ehrh.), and Norway spruce (Picea abies (L.) Karst.), and constitutes $8 \%$ and $9 \%$ of the total forest land and volume, respectively. Data consist of two sets: our measured stands at the age of 101 to 140 years, and NFI (2014-2018) measured stands at the age of 41 to 100 years (Figure 1).

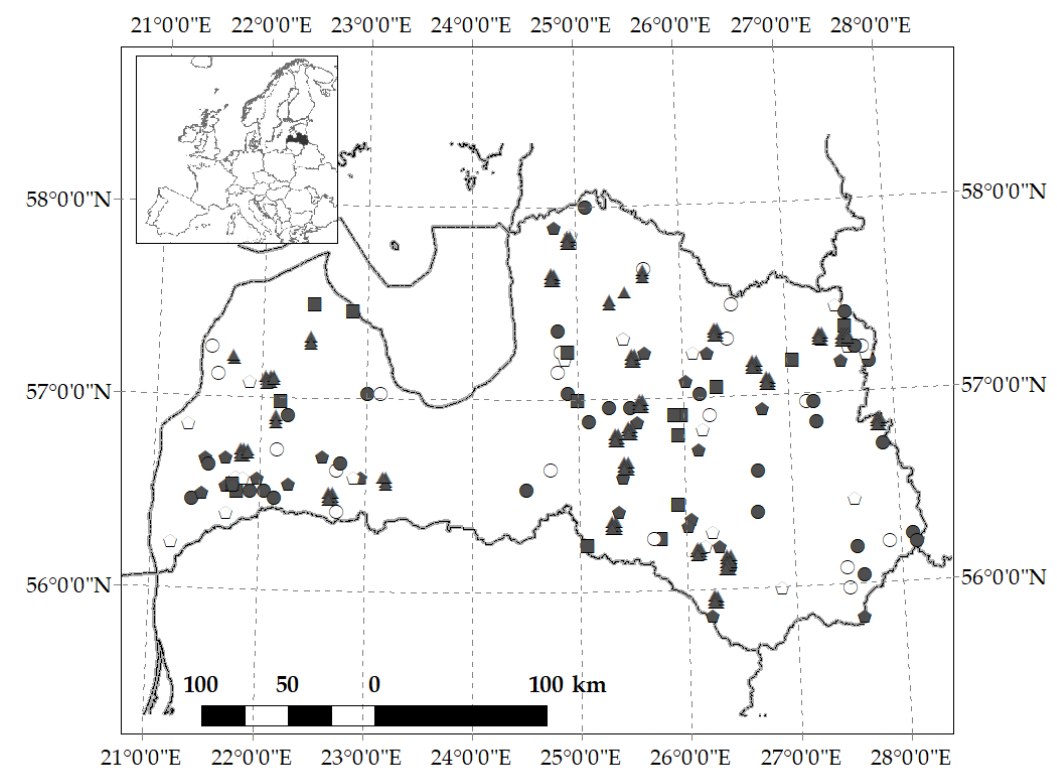

Figure 1. Distribution of sample plots in mature $(\bullet, 41-60$ years) moderately overmature $(\bullet$, 61-80 years), overmature ( $\mathbf{\square}, 81-100$ years), and old-growth $(\boldsymbol{\Lambda}, 101-140$ years) European aspen (Populus tremula L.) stands, with dark symbols indicating unmanaged stands in all age groups, and clear circles $(\bigcirc)$ and pentagons $(\bullet)$ indicating managed mature and moderately overmature stands.

Our measured stands were randomly pre-selected from protected forests across Latvia, based on species composition (at least $50 \%$ of the overstory growing stock comprised by aspen), age limit ( $\geq 101$ years), and site type. We included stands located on Hylocomiosa and Oxalidosa (local classification by Bušs [36] site types on fertile mesic mineral soils, as these are two the most common site types (17\% and $44 \%$ of the area, respectively) for the aspen-dominated stands in Latvia. The selected forests have various types of protection determined by legislation and voluntary by state forests, mostly microreserves for protected species and habitats. These forests have received no silvicultural measures for at least four decades, although no documentation of prior management was available. Sites that showed signs of former logging were excluded. Only sites that met all aforementioned 
criteria were measured. Overall, our study included 150 sample plots (mean 5.8 plots per stand) from 26 aspen-dominated stands at the age of 104 to 134 years (Table 1). Throughout this paper, this group is referred to as 'old-growth stands' (101-140 years), with the degree of naturalness based on the Buchwald [37] classification 'n6-Old-growth forest'.

Table 1. Characteristics (marginal mean \pm standard error) of old-growth European aspen (Populus tremula L.) stands.

\begin{tabular}{|c|c|c|c|c|c|c|c|c|c|c|}
\hline \multirow{3}{*}{ No. } & \multirow{3}{*}{$\mathbf{N}$} & \multicolumn{6}{|c|}{ Overstory } & \multicolumn{2}{|c|}{ Understory } & \multirow{3}{*}{$\begin{array}{l}\text { CWD } \\
\text { Volume, } \\
\text { m }^{3} \mathrm{ha}^{-1}\end{array}$} \\
\hline & & \multicolumn{2}{|c|}{ Species } & \multirow{2}{*}{$\mathbf{A}$} & \multirow{2}{*}{$\mathrm{DBH}, \mathrm{cm}$} & \multirow{2}{*}{ Height, m } & \multirow{2}{*}{$\begin{array}{l}\text { Growing Stock, } \\
\mathrm{m}^{3} \mathrm{ha}^{-1}\end{array}$} & \multirow{2}{*}{ Species } & \multirow{2}{*}{$\begin{array}{l}\text { Growing Stock, } \\
\mathrm{m}^{3} \mathrm{ha}^{-1}\end{array}$} & \\
\hline & & Aspen & Other & & & & & & & \\
\hline 1 & 6 & 10 & - & 109 & $49.0 \pm 1.6$ & $39.4 \pm 0.1$ & $687 \pm 99$ & 5S5L & $118.3 \pm 28.6$ & $123.5 \pm 9.7$ \\
\hline 2 & 6 & 9 & $1 S$ & 114 & $57.1 \pm 3.2$ & $38.2 \pm 0.3$ & $555 \pm 40$ & 5S5L & $116.3 \pm 20.7$ & $142.2 \pm 20.5$ \\
\hline 3 & 6 & 9 & $1 S$ & 118 & $48.0 \pm 1.7$ & $38.1 \pm 0.2$ & $602 \pm 42$ & $10 S$ & $168.8 \pm 14.9$ & $28.1 \pm 10.1$ \\
\hline 4 & 6 & 9 & $1 \mathrm{~B}$ & 118 & $44.0 \pm 2.2$ & $38.9 \pm 0.5$ & $620 \pm 83$ & $10 S$ & $78.0 \pm 14.4$ & $111.2 \pm 10.5$ \\
\hline 5 & 6 & 10 & - & 108 & $46.0 \pm 1.9$ & $39.5 \pm 0.2$ & $812 \pm 55$ & $10 S$ & $111.8 \pm 16.6$ & $79.6 \pm 15.4$ \\
\hline 6 & 8 & 7 & 1B1P1S & 109 & $41.0 \pm 2.7$ & $32.1 \pm 0.6$ & $623 \pm 73$ & 9S1Ba & $126.8 \pm 12.8$ & $75.2 \pm 15.2$ \\
\hline 7 & 8 & 8 & $2 \mathrm{~B}$ & 106 & $47.0 \pm 2.7$ & $32.3 \pm 0.5$ & $471 \pm 31$ & 8S1O1B & $81.3 \pm 13.2$ & $50.3 \pm 13.0$ \\
\hline 8 & 3 & 9 & $1 \mathrm{~B}$ & 134 & $53.5 \pm 0.8$ & $35.2 \pm 0.1$ & $579 \pm 90$ & 9S1A & $224.4 \pm 21.0$ & $61.0 \pm 27.8$ \\
\hline 9 & 6 & 8 & 1S1B & 114 & $44.9 \pm 2.0$ & $36.7 \pm 0.2$ & $628 \pm 50$ & $10 S$ & $109.4 \pm 11.4$ & $113.4 \pm 10.4$ \\
\hline 10 & 6 & 9 & $1 S$ & 104 & $55.6 \pm 2.8$ & $39.2 \pm 0.7$ & $783 \pm 66$ & $10 S$ & $193.7 \pm 17.8$ & $137.8 \pm 29.0$ \\
\hline 11 & 6 & 8 & 1B1S & 113 & $56.1 \pm 2.9$ & $38.7 \pm 0.2$ & $753 \pm 35$ & $10 S$ & $138.9 \pm 13.9$ & $74.9 \pm 13.7$ \\
\hline 12 & 6 & 9 & $1 S$ & 109 & $47.3 \pm 1.7$ & $38.4 \pm 0.1$ & $770 \pm 51$ & 6S3L1A & $67.8 \pm 11.5$ & $59.7 \pm 11.0$ \\
\hline 13 & 6 & 8 & $2 S$ & 104 & $46.3 \pm 2.2$ & $37.2 \pm 0.7$ & $601 \pm 52$ & 7S3L & $105.8 \pm 19.0$ & $60.2 \pm 9.1$ \\
\hline 14 & 6 & 9 & $1 S$ & 104 & $49.3 \pm 2.0$ & $39.3 \pm 0.2$ & $712 \pm 71$ & 9S1L & $95.4 \pm 12.1$ & $174.1 \pm 22.9$ \\
\hline 15 & 6 & 8 & $2 S$ & 117 & $47.7 \pm 2.1$ & $33.0 \pm 0.5$ & $598 \pm 52$ & $10 S$ & $122.5 \pm 20.3$ & $104.5 \pm 21.8$ \\
\hline 16 & 6 & 8 & $1 S$ & 117 & $54.2 \pm 1.2$ & $36.2 \pm 0.1$ & $761 \pm 69$ & 5S4L1B & $46.2 \pm 3.1$ & $70.0 \pm 15.4$ \\
\hline 17 & 6 & 9 & $1 \mathrm{~B}$ & 116 & $52.0 \pm 2.4$ & $39.1 \pm 0.2$ & $721 \pm 64$ & 7S2L1M & $85.4 \pm 9.5$ & $26.6 \pm 10.7$ \\
\hline 18 & 6 & 9 & $1 S$ & 111 & $50.1 \pm 3.6$ & $39.9 \pm 0.3$ & $950 \pm 77$ & $10 S$ & $90.3 \pm 8.6$ & $94.6 \pm 14.9$ \\
\hline 19 & 6 & 10 & - & 118 & $45.2 \pm 1.1$ & $37.1 \pm 0.2$ & $764 \pm 48$ & 9S1L & $185.3 \pm 27.5$ & $147.4 \pm 27.6$ \\
\hline 20 & 6 & 7 & 2S1B & 107 & $52.0 \pm 2.9$ & $37.4 \pm 0.4$ & $622 \pm 60$ & $10 S$ & $99.9 \pm 9.6$ & $132.5 \pm 35.4$ \\
\hline 21 & 6 & 7 & 2S1B & 113 & $51.6 \pm 2.2$ & $36.4 \pm 0.3$ & $709 \pm 71$ & $10 S$ & $106.6 \pm 14.9$ & $112.3 \pm 18.7$ \\
\hline 22 & 4 & 9 & $1 S$ & 107 & $50.4 \pm 2.9$ & $33.8 \pm 0.2$ & $381 \pm 37$ & 5Ga3As1Bc1S & $14.1 \pm 3.3$ & $71.0 \pm 34.9$ \\
\hline 23 & 2 & 5 & $4 \mathrm{P} 1 \mathrm{O}$ & 117 & $37.8 \pm 10.1$ & $27.6 \pm 3.2$ & $446 \pm 31$ & 9L1S & $5.3 \pm 0.0$ & $10.7 \pm 3.8$ \\
\hline 24 & 3 & 9 & $1 \mathrm{~B}$ & 104 & $41.4 \pm 1.5$ & $29.4 \pm 0.3$ & $617 \pm 61$ & 9S1B & $77.0 \pm 14.0$ & $56.8 \pm 42.2$ \\
\hline 25 & 8 & 8 & 1S1B & 118 & $46.7 \pm 2.0$ & $37.7 \pm 0.2$ & $599 \pm 47$ & 9S1M & $131.9 \pm 14.5$ & $106.5 \pm 24.6$ \\
\hline 26 & 6 & 9 & $1 S$ & 108 & $55.6 \pm 2.1$ & $38.1 \pm 0.1$ & $689 \pm 50$ & $8 \mathrm{~S} 2 \mathrm{M}$ & $102.5 \pm 7.2$ & $99.3 \pm 20.6$ \\
\hline
\end{tabular}

$\mathrm{N}$-number of sample plots; species composition is based on the proportion of the species growing stock in the respective stand layer: $10=90 \% \ldots 100 \%, 9=80 \% \ldots 89 \%, 8=70 \% \ldots . .79 \%$, etc. A—aspen; S-spruce (Picea abies (L.) Karst.); B-birch (pooled Betula pendula Roth and Betula pubescens Ehrh.); P-pine (Pinus sylvestris L.); L-lime (Tilia cordata Mill.); Ba-black alder (Alnus glutinosa (L.) Gaertn.); O—oak (Quercus robur L.); As—ash (Fraxinus excelsior L.); M-maple (Acer platanoides L.); Ga—gray alder (Alnus incana (L.) Moench); Bc—bird cherry (Padus avium Mill.).

All measurements were performed in 2019. In each sample plot, for living trees, a diameter at breast height $(\mathrm{DBH})$ of $\geq 6.1 \mathrm{~cm}$ was measured using a caliper (accuracy $\pm 0.1 \mathrm{~cm}$ ), and data on species and stand layer were noted. Height was measured using Vertex clinometer (accuracy $0.1 \mathrm{~m}$ ) for five overstory and three understory trees of the dominant species; stand height was estimated by corresponding height to the quadratic mean diameter of overstory aspen. The same overstory trees were sampled by increment cores to measure age. For each standing dead tree (stems and snags), we measured DBH $\geq 6.1 \mathrm{~cm}$ and height and noted species (aspen, other deciduous, or coniferous) and decay class. For lying CWD, we measured length $(\geq 1.0 \mathrm{~m})$ using a ruler (accuracy $0.1 \mathrm{~m}$ ) and the diameter at both ends (diameter at thicker end $\geq 6.1 \mathrm{~cm}$ ), and noted species (aspen, other deciduous, or coniferous) and decay class at the thickest end. The decay class was observed visually and using the 'knife method'. All CWD was divided into five decay classes (applied from Mäkinen et al. [38], Table 2). 
Table 2. Description of decay classes, density (dry weight per raw volume), and carbon concentration [38]. Basic density and carbon concentration are applied from Köster et al. [39].

\begin{tabular}{|c|c|c|c|c|}
\hline & Decay Class & Description & $\begin{array}{l}\text { Basic Density, } \\
\mathrm{kg} \mathrm{m}^{3}\end{array}$ & $\begin{array}{c}\text { Carbon } \\
\text { Concentration, } \%\end{array}$ \\
\hline 1 & Recently dead & $\begin{array}{c}\text { Wood hard, knife blade penetrates a few millimeters. } \\
\text { Bark attached to the stem. }\end{array}$ & 391.3 & 47.2 \\
\hline 2 & Weakly decayed & $\begin{array}{l}\text { The outer layer of wood starts to soften, knife blade } \\
\text { penetrates } 1-2 \mathrm{~cm} \text {. Loose bark, branches present. }\end{array}$ & 330.6 & 47.4 \\
\hline 3 & Moderately decayed & $\begin{array}{l}\text { The wood of outer layers of stem soft, the core still hard, } \\
\text { knife blade penetrates }<5 \mathrm{~cm} \text {. Loose, fragmented bark. }\end{array}$ & 230.6 & 47.4 \\
\hline 4 & Very decayed & $\begin{array}{l}\text { Wood soft through the log, knife blade penetrates the } \\
\text { wood in its entirety. No branches, most of the surface } \\
\text { covered with mosses. }\end{array}$ & 161.1 & 46.6 \\
\hline 5 & $\begin{array}{l}\text { Almost completely } \\
\text { decomposed }\end{array}$ & $\begin{array}{l}\text { Lost consistency of wood, breaks up easily. Surface } \\
\text { covered with lichens, mosses, and dwarf shrubs. }\end{array}$ & 60.7 & 46.3 \\
\hline
\end{tabular}

National Forest Inventory (NFI, 2014-2018) data with the corresponding parameters were used (Table 3). We selected 111 sample plots with an overstory dominated by aspen (at least $40 \%$ of the growing stock) at the age of 41 to 100 years, growing on Hylocomiosa and Oxalidosa site types. The selected plots were divided into 'managed' and 'unmanaged' based on the presence of fresh stumps found during the previous 15 years (since the first NFI measurement), while no information on tree removal before that time was available. The NFI data were first used to characterize the mean quantity of CWD and CWD carbon pool in managed and unmanaged stands, followed by further assessment of unmanaged stands only. The selected NFI plots were divided into age groups of 'mature stands' at the age of 41 to 60 years, 'moderately overmature' at the age of 61 to 80 years, and 'overmature' at the age of 81 to 100 years, and are referred respectively throughout this paper.

Table 3. Characteristics (marginal mean \pm standard error) of mature (41-60 years), moderately overmature (61-80 years), overmature (81-100 years), and old-growth (101-140 years) European aspen (Populus tremula L.) stands according to management type.

\begin{tabular}{|c|c|c|c|c|c|c|}
\hline \multirow{3}{*}{ Characteristics } & \multicolumn{6}{|c|}{ Stand Type and Age } \\
\hline & \multicolumn{2}{|c|}{ Managed } & \multicolumn{4}{|c|}{ Unmanaged } \\
\hline & $41-60$ & $61-80$ & $41-60$ & $61-80$ & 81-100 & 101-140 \\
\hline Stand age, years & $50.1 \pm 1.3$ & $67.9 \pm 1.1$ & $53.1 \pm 1.0$ & $70.1 \pm 1.2$ & $86.9 \pm 1.1$ & $111.8 \pm 0.5$ \\
\hline Site index, m & $28.0 \pm 1.0$ & $27.2 \pm 1.0$ & $28.8 \pm 0.4$ & $27.3 \pm 0.7$ & $25.7 \pm 0.8$ & $25.4 \pm 0.2$ \\
\hline $\mathrm{DBH}, \mathrm{cm}$ & $36.2 \pm 2.2$ & $42.8 \pm 2.7$ & $37.1 \pm 1.5$ & $39.5 \pm 1.3$ & $50.4 \pm 2.2$ & $49.0 \pm 0.6$ \\
\hline Height, m & $28.0 \pm 1.1$ & $31.9 \pm 1.1$ & $29.7 \pm 0.4$ & $32.4 \pm 0.7$ & $33.8 \pm 0.9$ & $36.8 \pm 0.2$ \\
\hline Total basal area, $\mathrm{m}^{2} \mathrm{ha}^{-1}$ & $29.2 \pm 2.5$ & $34.2 \pm 3.0$ & $32.2 \pm 1.4$ & $39.5 \pm 2.3$ & $41.8 \pm 1.9$ & $50.3 \pm 0.9$ \\
\hline Total growing stock, $\mathrm{m}^{3} \mathrm{ha}^{-1}$ & $330 \pm 30$ & $447 \pm 48$ & $377 \pm 21$ & $526 \pm 36$ & $577 \pm 37$ & $774 \pm 16$ \\
\hline Total number of trees, $\mathrm{ha}^{-1}$ & $1388 \pm 245$ & $1049 \pm 241$ & $1421 \pm 173$ & $1087 \pm 143$ & $942 \pm 108$ & $1134 \pm 67$ \\
\hline Overstory basal area, $\mathrm{m}^{2} \mathrm{ha}^{-1}$ & $21.8 \pm 1.7$ & $26.1 \pm 2.6$ & $24.3 \pm 1.5$ & $29.9 \pm 2.3$ & $30.4 \pm 1.7$ & $38.9 \pm 0.8$ \\
\hline Overstory growing stock, $\mathrm{m}^{3}$ ha ${ }^{-1}$ & $278 \pm 26$ & $383 \pm 45$ & $320 \pm 21$ & $443 \pm 36$ & $470 \pm 34$ & $664 \pm 14$ \\
\hline Overstory number of trees, ha ${ }^{-1}$ & $308 \pm 34$ & $262 \pm 29$ & $366 \pm 34$ & $345 \pm 33$ & $229 \pm 25$ & $246 \pm 7$ \\
\hline Aspen basal area, $\mathrm{m}^{2} \mathrm{ha}^{-1}$ & $14.0 \pm 2.0$ & $17.6 \pm 2.4$ & $14.6 \pm 1.2$ & $20.3 \pm 2.3$ & $21.9 \pm 2.1$ & $32.1 \pm 0.8$ \\
\hline Aspen growing stock, $\mathrm{m}^{3} \mathrm{ha}^{-1}$ & $187 \pm 25$ & $276 \pm 42$ & $205 \pm 18$ & $316 \pm 38$ & $355 \pm 39$ & $566 \pm 15$ \\
\hline Aspen number of trees, $\mathrm{ha}^{-1}$ & $363 \pm 139$ & $162 \pm 35$ & $296 \pm 71$ & $273 \pm 68$ & $126 \pm 18$ & $202 \pm 18$ \\
\hline Objects & 19 & 19 & 30 & 26 & 17 & 26 \\
\hline Sample plots & 19 & 19 & 30 & 26 & 17 & 150 \\
\hline
\end{tabular}

Latvian National Forest Inventory data are used for mature, moderately overmature, and overmature stands, and our measured data are used for old-growth stands. 
Jansons and Līcìte [40] describe inventory plot sampling design in detail. All measurements were performed in circular sample plots $\left(500 \mathrm{~m}^{2}\right)$. If the sample plot crossed two distinctly different stands, it was divided into sectors. Only plots with a sector area of $\geq 400 \mathrm{~m}^{2}$ were used in this study. For all overstory trees, DBH was measured, and the stand basal area was calculated. Tree height was measured for 8 to 19 trees of each overstory species, depending on the number of species in the plot, and stand height was calculated. Increment cores of three overstory trees were used to determine stand age. Measurements of CWD were conducted using a concentric design: within a $12.62 \mathrm{~m}$ radius, standing CWD with a diameter at breast height and lying CWD with a diameter of the thicker end $\geq 14.1 \mathrm{~cm}$ was measured; and within a $5.64 \mathrm{~m}$ radius, CWD with a respective diameter $\geq 6.1 \mathrm{~cm}$ was measured. Height of all standing trees and length $(\geq 1.0 \mathrm{~m})$ of lying trees was measured, and decay class and species (aspen, other deciduous, or coniferous) were noted. CWD was divided into three groups, according to decay class: 'recently dead' with wood hard, bark intact, 'moderately decayed' with all succeeding phases of decomposition starting from loose bark to the cover of epiphytic mosses on $<10 \%$ of the visible stem surface, and 'very decayed' with a cover of epiphytic mosses on $\geq 10 \%$ of the visible stem surface. Our measured decay classes were integrated according to NFI descriptions to compare the volume of CWD among decay classes at different stand ages. The adjusted decay classes were (1) 'recently dead', (2) 'weakly decayed', and $(3+4+5)$ 'moderately to almost completely decomposed' (Table 2).

For both data sets, the volume of whole trees was calculated using equations developed by Liepa [41], and the volume of stumps and snags was calculated using Huber's formula (Equation (1)). For CWD carbon pool calculation, volume was converted to mass using decay class-specific density and carbon content for aspen (Table 2), both applied from a study by Köster et al. [39].

Huber's formula:

$$
\mathrm{V}=\frac{\mathrm{L} \pi \mathrm{d}_{\mathrm{m}}{ }^{2}}{4}
$$

$\mathrm{V}=$ Stump $/$ snag volume,

$\mathrm{L}=$ Length of the log or height of the stump, and

$\mathrm{d}_{\mathrm{m}}=$ Mid-diameter of the log or the stump.

We used linear mixed models, incorporating 'stand' as a random effect (several plots were measured in the same stand) to assess how quantities of CWD and CWD carbon pool differed among groups based on stand parameters (age, site index, basal area), stand management, CWD pose, species composition, and decay class. The same models were used to calculate marginal mean values of stand and CWD parameters and their standard errors. Data were analyzed using SPSS 14.0 for Windows; all tests were performed at $\alpha=0.05$.

\section{Results}

We did not find a significant (both $p>0.05$ ) difference between managed and unmanaged stands within both mature and moderately overmature stands (Table 4 ). as well as no significant difference (all $p>0.05$ ) appeared among the age groups.

Lying CWD was $62 \%$ to $85 \%$ of the total volume among the age groups and management types, however, we did not find significant differences $(p>0.05)$ for quantities of standing and lying CWD among the stand age groups of each management type, with the exception of significantly lower standing CWD volume in unmanaged mature stands compared to that in old-growth stands $(p<0.05)$. The CWD carbon pool size also had no significant differences $(p>0.05)$ among stand age groups for each CWD type and in total, with the exception of significantly higher standing CWD carbon pool in old-growth stands compared to that in unmanaged mature and moderately overmature stands (both $p<0.05$ ). 
Table 4. Coarse woody debris (CWD) volume and CWD carbon pool size in mature (41-60 years), moderately overmature (61-80 years), overmature (81-100 years), and old-growth (101-140 years) European aspen (Populus tremula L.) stands by CWD pose and stand type.

\begin{tabular}{|c|c|c|c|c|c|c|c|}
\hline \multirow{2}{*}{ CWD Pose } & \multirow{2}{*}{ Stand Type } & \multirow{2}{*}{$\begin{array}{c}\text { Stand Age, } \\
\text { Years }\end{array}$} & \multirow{2}{*}{$\begin{array}{l}\text { Number of } \\
\text { Sample Plots }\end{array}$} & \multicolumn{2}{|c|}{ CWD Volume, $\mathrm{m}^{3} \cdot \mathrm{ha}^{-1}$} & \multicolumn{2}{|c|}{ CWD Carbon Pool, $\mathrm{t} \cdot \mathrm{ha}^{-1}$} \\
\hline & & & & Marginal Mean & SE & Marginal Mean & SE \\
\hline \multirow{6}{*}{ Standing } & \multirow{2}{*}{ Managed } & $41-60$ & 19 & 7.6 & 6.0 & 1.0 & 0.9 \\
\hline & & $61-80$ & 19 & 5.3 & 6.0 & 0.7 & 0.9 \\
\hline & \multirow{4}{*}{ Unmanaged } & $41-60$ & 30 & 16.6 & 4.8 & 2.2 & 0.7 \\
\hline & & $61-80$ & 26 & 13.8 & 5.2 & 1.9 & 0.7 \\
\hline & & $81-100$ & 17 & 26.1 & 6.4 & 3.5 & 0.9 \\
\hline & & $101-140$ & 150 & 31.9 & 2.2 & 4.6 & 0.3 \\
\hline \multirow{6}{*}{ Lying } & \multirow{2}{*}{ Managed } & $41-60$ & 19 & 12.5 & 12.0 & 1.4 & 1.5 \\
\hline & & $61-80$ & 19 & 31.0 & 12.0 & 4.1 & 1.5 \\
\hline & \multirow{4}{*}{ Unmanaged } & $41-60$ & 30 & 53.3 & 9.6 & 6.6 & 1.2 \\
\hline & & $61-80$ & 26 & 53.5 & 10.3 & 6.4 & 1.3 \\
\hline & & $81-100$ & 17 & 47.5 & 12.9 & 5.3 & 1.6 \\
\hline & & $101-140$ & 150 & 60.5 & 4.3 & 8.0 & 0.5 \\
\hline \multirow{6}{*}{ Total } & \multirow{2}{*}{ Managed } & $41-60$ & 19 & 20.1 & 14.2 & 2.4 & 1.8 \\
\hline & & $61-80$ & 19 & 36.3 & 14.2 & 4.8 & 1.8 \\
\hline & \multirow{4}{*}{ Unmanaged } & $41-60$ & 30 & 69.9 & 11.3 & 8.7 & 1.5 \\
\hline & & $61-80$ & 26 & 67.3 & 12.1 & 8.2 & 1.6 \\
\hline & & 81-100 & 17 & 73.5 & 15.3 & 8.8 & 2.0 \\
\hline & & $101-140$ & 150 & 92.4 & 5.1 & 12.5 & 0.7 \\
\hline
\end{tabular}

Latvian National Forest Inventory data are used for mature, moderately overmature, and overmature stands, and our measured data are used for old-growth stands. SE-standard error.

We further analyzed deadwood characteristics within unmanaged stands. Stand age and site index were significant factors for CWD volume and CWD carbon pool (all $p<0.001$ ), contrary to stand basal area (both $p>0.05$ ). However, this was described by only weak positive correlations between both stand age and site index and CWD volume (for both $p<0.05, \mathrm{r}=0.15)$ and CWD carbon pool size $(p<0.01, \mathrm{r}=0.19$ and $p<0.05, \mathrm{r}=0.14$, respectively).

A large CWD volume was frequently present in assessed stands (Figure 2). The volume of at least $20 \mathrm{~m}^{3} \mathrm{ha}^{-1}$ was found in $77 \%$ to $89 \%$ of sample plots depending on stand age. This proportion gradually decreased for larger CWD quantities, yet, at least $50 \mathrm{~m}^{3} \mathrm{ha}^{-1}$ was present in $43 \%$ to $75 \%$ of sample plots.

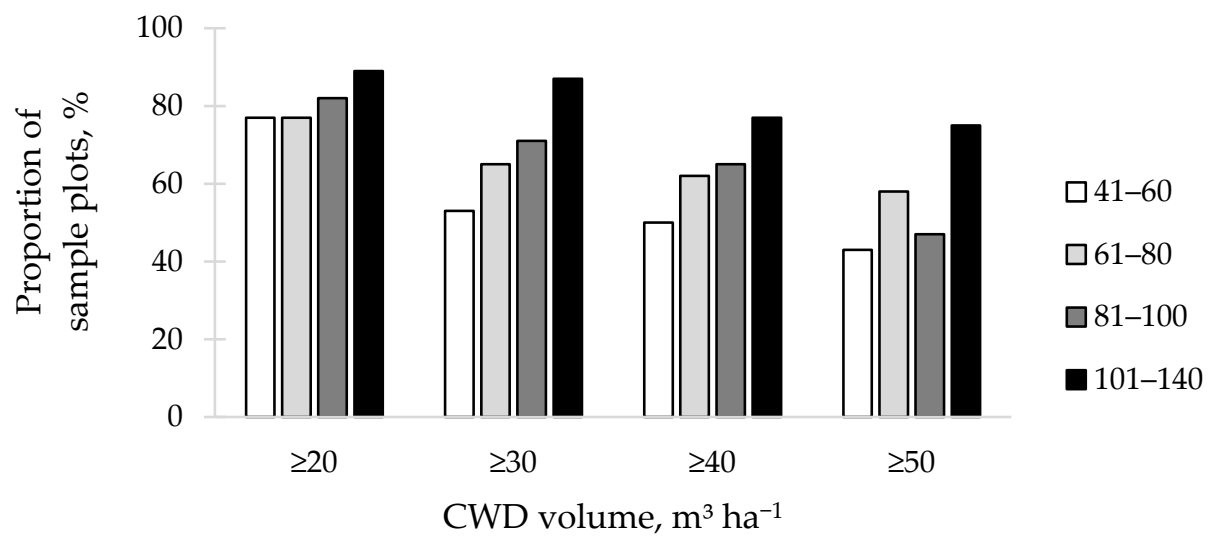

Figure 2. Occurrence of a particular coarse woody debris (CWD) volume according to stand age in unmanaged European aspen (Populus tremula L.) stands. 
Most of the CWD consisted of deciduous deadwood (Figure 3). Aspen and other deciduous species (mostly Betula pendula Roth, B. pubescens Ehrh., Alnus incana (L.) Moench, Corylus avellana $\mathrm{L}$, and Salix caprea $\mathrm{L}$.) together accounted for $55 \%$ to $85 \%$ of CWD among the stand age groups. The proportion of aspen CWD was similar (all $p>0.05$ ) in all age groups. The proportion of coniferous CWD was similar among mature, moderately overmature, and overmature stands (all $p>0.05$ ), and in all these age groups, coniferous deadwood constituted a significantly higher $(p<0.05)$ portion of CWD than that in old-growth stands. For deciduous deadwood, significant $(p<0.05)$ differences were only found between mature and old-growth stands.

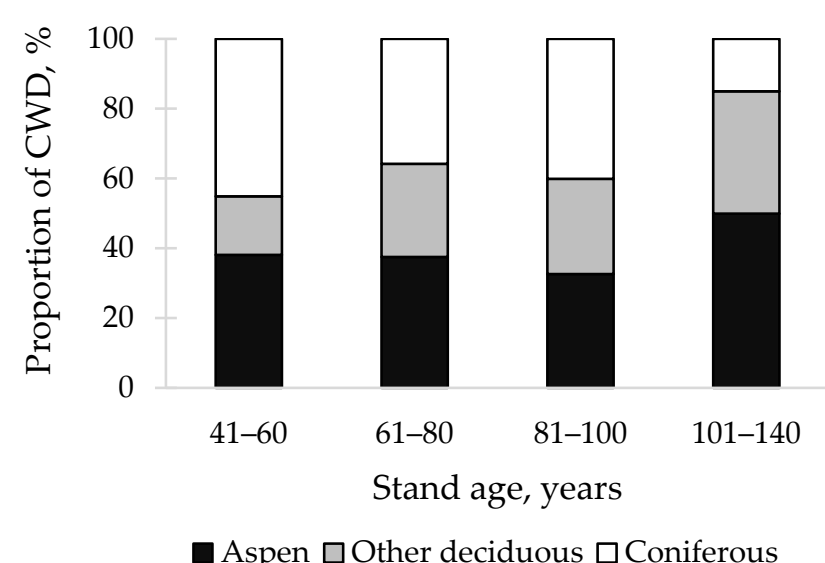

Figure 3. The proportion of coarse woody debris (CWD) by groups of species (aspen, other deciduous, and coniferous) in mature (41-60 years), moderately overmature (61-80 years), overmature (81-100 years), and old-growth (101-140 years) unmanaged European aspen (Populus tremula L.) stands.

Mean CWD diameter was $15.6 \pm 1.4 \mathrm{~cm}$ ( \pm standard error) in mature stands, $20.9 \pm 1.4 \mathrm{~cm}$ in moderately overmature, $20.4 \pm 1.8 \mathrm{~cm}$ in overmature, and $20.6 \pm 0.6 \mathrm{~cm}$ in old-growth stands. Mature stands had a significantly thinner mean diameter of debris than old-growth stands $(p<0.05)$, but similar to that in both groups of overmature stands (both $p>0.05$ ).

The volume of large CWD tended to increase with stand age, yet no significant differences (all $p>0.05$ ) were found within each diameter group (Figure 4). About half of the CWD volume consisted of debris larger than $30 \mathrm{~cm}$ in diameter: from $48 \%$ $\left(33.5 \pm 9.3 \mathrm{~m}^{3} \mathrm{ha}^{-1}\right)$ in mature stands to $64 \%\left(47.3 \pm 12.3 \mathrm{~m}^{3} \mathrm{ha}^{-1}\right)$ in overmature stands. Moreover, debris with a diameter greater than $40 \mathrm{~cm}$ formed from $19 \%\left(13.2 \pm 7.0 \mathrm{~m}^{3} \mathrm{ha}^{-1}\right)$ in mature stands to $44 \%\left(32.3 \pm 9.2 \mathrm{~m}^{3} \mathrm{ha}^{-1}\right)$ in overmature stands.

We used adjusted decay classes to assess differences in CWD volume among stand age groups (Figure 5). The most distinct differences were found for recently dead wood, with the highest volume of such CWD in old-growth and mature stands: $12 \%$ and $17 \%$, respectively. However, old-growth stands had significantly higher recently dead CWD volume than both overmature stand groups (both $p<0.05$ ), while mature stands had no significant differences from others (all $p>0.05$ ). The proportion of weakly decayed debris was similar in all age groups, ranging from $31 \%$ of total CWD in moderately overmature to $40 \%$ in mature stands. 
(a) $>10 \mathrm{~cm}$

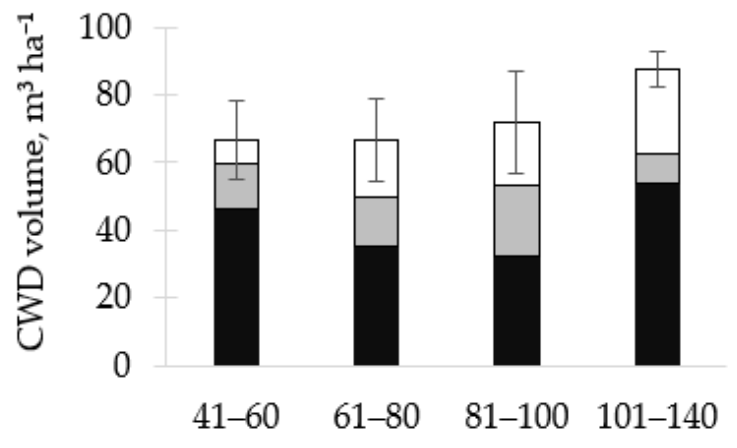

Stand age, years

(c) $>30 \mathrm{~cm}$

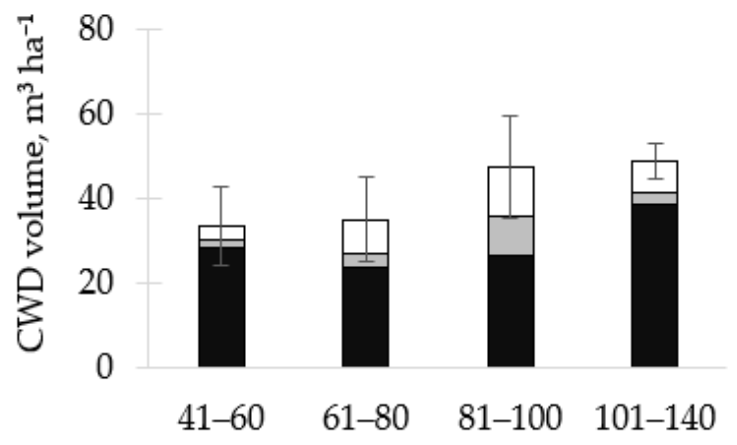

Stand age, years (b) $>20 \mathrm{~cm}$

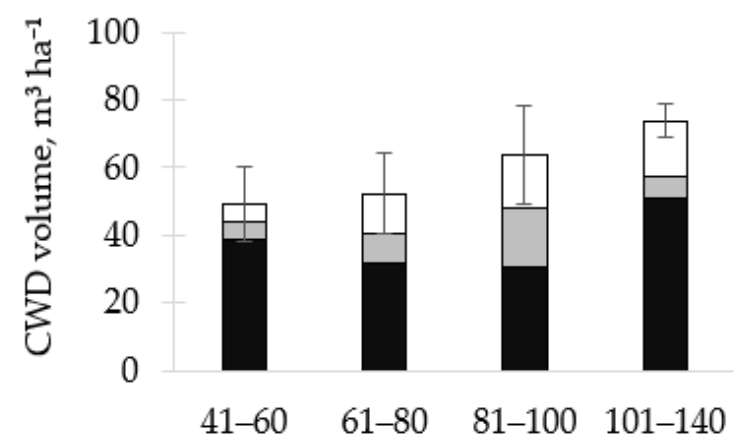

Stand age, years

(d) $>40 \mathrm{~cm}$

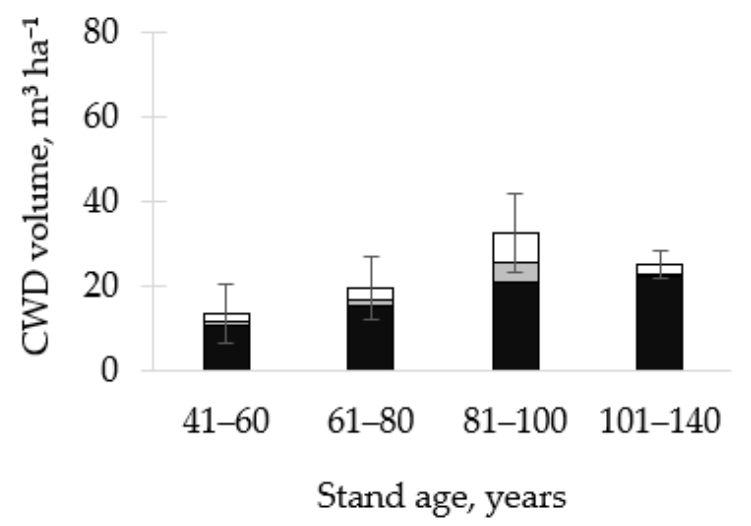

Figure 4. The marginal mean volume ( \pm standard error of total volume) of aspen (black stacked bars), other deciduous (gray stacked bars) and coniferous (clear stacked bars) coarse woody debris (CWD) in mature (41-60 years; $n=30$ ), moderately overmature (61-80 years; $n=26)$, overmature (81-100 years; $n=17)$, and old-growth $(101-140$ years; $n=150)$ unmanaged European aspen (Populus tremula L.) stands by groups of CWD diameter: (a) $>10 \mathrm{~cm},(\mathbf{b})>20 \mathrm{~cm},(\mathbf{c})>30 \mathrm{~cm}$, and (d) $>40 \mathrm{~cm}$.

In all stand age groups, moderately to almost completely decomposed wood formed from $44 \%\left(40.4 \pm 3.5 \mathrm{~m}^{3} \mathrm{ha}^{-1}\right)$ in old-growth stands to $68 \%\left(45.6 \pm 8.9 \mathrm{~m}^{3} \mathrm{ha}^{-1}\right)$ in moderately overmature stands. In old-growth stands, CWD distribution was categorized into five decay classes. The first two were the same as for adjusted decay classes (Figure 5), moderately decayed CWD accounted for $21 \%\left(19.8 \pm 1.8 \mathrm{~m}^{3} \mathrm{ha}^{-1}\right)$, and very decayed and almost completely decomposed CWD accounted for $14 \%\left(12.6 \pm 1.5 \mathrm{~m}^{3} \mathrm{ha}^{-1}\right)$ and $9 \%$ $\left(7.9 \pm 1.1 \mathrm{~m}^{3} \mathrm{ha}^{-1}\right)$ of total CWD in old-growth stands, respectively. 
(a) 1

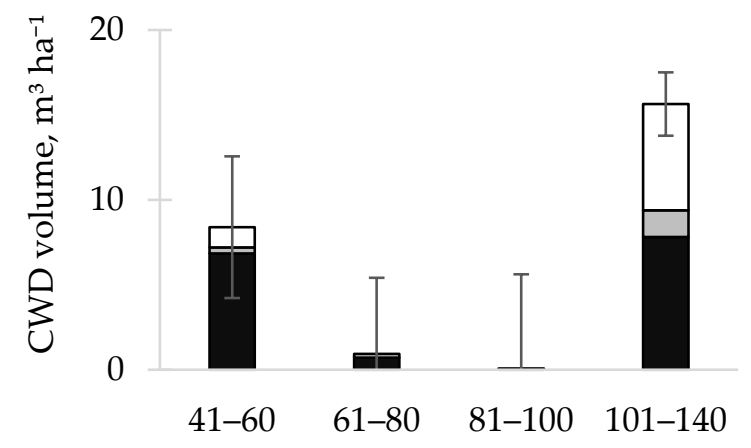

Stand age, years

(b) 2

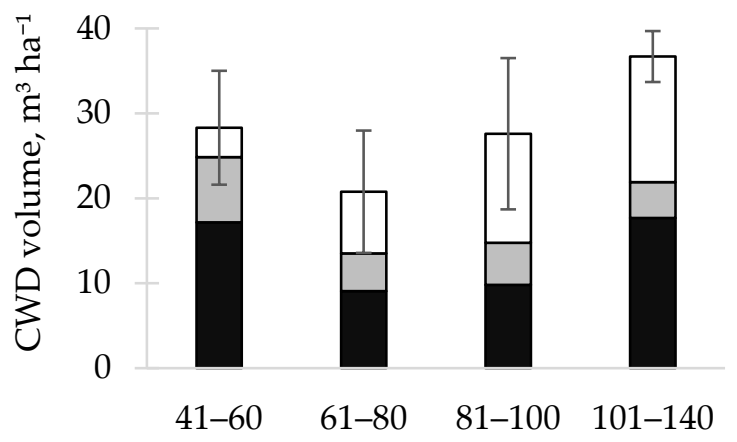

Stand age, years

(c) $3+4+5$

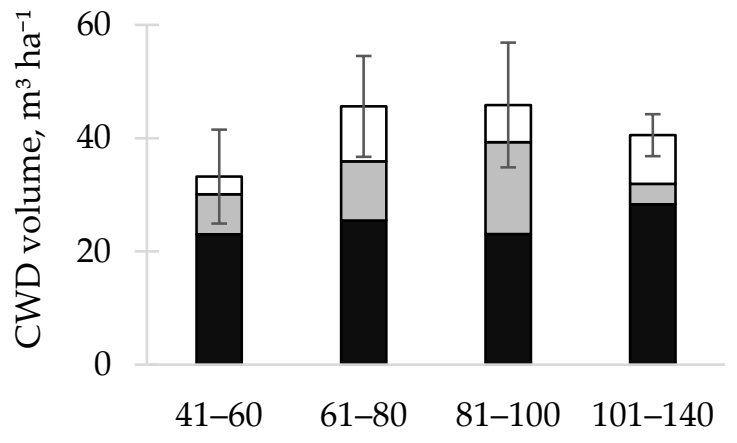

Stand age, years

Figure 5. The marginal mean volume ( \pm standard error) of coarse woody debris (CWD) in mature (41-60 years; $n=30)$, moderately overmature (61-80 years; $n=26)$, overmature ( $81-100$ years; $n=17)$, and old-growth (101-140 years; $\mathrm{n}=150$ ) unmanaged European aspen (Populus tremula L.) stands by adjusted decay classes: (1) recently dead, (2) weakly decayed, and $(3+4+5)$ moderately to almost completely decomposed.

\section{Discussion}

This study characterizes CWD volume, composition, and structure in aspen stands from mature to old-growth age. The information on the histories of the studied old-growth stands is not available; however, we assume that the age of the overstory corresponds well with time since stand origin after disturbance. The present stand composition with aspen 
as the dominant species in the overstory could almost exclusively form only if regeneration of the species is abundant enough, i.e., after a large-scale disturbance, such as forest fire or clear-cutting. This is supported by the species-specific regeneration requirements, as aspen is essentially a pioneer species [9], with limited regeneration capacity under lack of sufficiently large canopy gaps [42-44], and as a shade-intolerant species [45], it has difficulties to reach canopy-layer if regenerated in gaps.

We did not find a significant differences between managed and unmanaged stands, that could indicate an effect of the continuous removal of lower-dimension and vitality trees (i.e., potential deadwood) from the conventionally managed stands [46,47]. The CWD volume in the studied managed stands, however, considerably exceeded deadwood volume that is reported in other countries in Northern Europe: $5.9 \mathrm{~m}^{3} \mathrm{ha}^{-1}$ for managed stands in Finland [48], $7.6 \mathrm{~m}^{3} \mathrm{ha}^{-1}$ for managed stands in Sweden [47], and $13.7 \mathrm{~m}^{3} \mathrm{ha}^{-1}$ across forests in Estonia [49]. Our results are also somewhat higher than the mean CWD volume across forests in Latvia for managed and unmanaged stands together: according to NFI, $19.8 \mathrm{~m}^{3} \mathrm{ha}^{-1}$. The studied unmanaged stands comprised about 70 to $90 \mathrm{~m}^{3} \mathrm{ha}^{-1}$, which is in between average deadwood volume of 40 to $170 \mathrm{~m}^{3} \mathrm{ha}^{-1}$ in boreal unmanaged forests [11,50-52].

As expected, age was a significant factor affecting CWD volume in the unmanaged stands since deadwood tends to accumulate under the absence of tree removal [53-55]. Such tendency has been often reported in coniferous-dominated forests $[8,17,47,54,56]$, whereas for birch, stand age was not a significant factor affecting CWD volume at the range of 71 to 150 years [33]. For trembling aspen (Populus tremuloides Michx.), the volume of CWD significantly increased for older stands and was comparable with our estimates: $63.1 \mathrm{~m}^{3} \mathrm{ha}^{-1}$ in young stands, $76.8 \mathrm{~m}^{3} \mathrm{ha}^{-1}$ in mature, and $101.4 \mathrm{~m}^{3} \mathrm{ha}^{-1}$ in old stands [57].

Site index showed a significant but very weak positive effect on CWD volume and was in accordance with results of other studies in younger stands [58-60]. However, another indicator of stand productivity, stand basal area, had a non-significant effect on CWD volume, presumably due to a wide range of the studied stand age.

In stands undergoing increased tree death from senescence and natural disturbance, a negative relationship between deadwood volume and stand basal area occur, i.e., disturbance decreases the basal area of living trees and simultaneously increases deadwood volume [8]. Our study only included stands where old aspen still formed the dominant cohort. The old aspen trees with large diameters were still alive and did not contributed to CWD, thus, lacking a relation between CWD volume and basal area. Likewise, the relation between basal area and CWD volume was absent in old-growth hemiboreal birch stands [33]. Both aspen and birch are pioneer species, typically undergoing canopy transition from early- to late-successional species after reaching their life span [61]. For aspen, lifespan commonly reaches 90 years [62], although species longevity might reach up to 200 years $[9,63]$. The studied old-growth stands were somewhere in between these ages, thus might represent stands in early senescence (see below), although aspen might persist in old-growth conditions for a prolonged time [44].

In European boreal forests, the majority of deadwood-dependent species need from 20 to $30 \mathrm{~m}^{3} \mathrm{ha}^{-1}$ deadwood for their presence [64]. Yet, deadwood volume per se is an insufficient measure [65-67], and additional characteristics are important for saproxylic species diversity. This includes deadwood species diversity, especially the abundance of temperate deciduous deadwood [47], and deadwood spatial and temporal continuity [68]. Our studied aspen stands had a high proportion of deciduous debris (pooled aspen and other deciduous species), accounting for 55\% of total CWD in mature stands to $85 \%$ in old-growth stands (Figure 3). The higher portion of coniferous deadwood in mature stands likely originated from understory spruce, which typically forms small fractions of debris due to self-thinning [11]. As stand ages, death from the senescence of aspen and other pioneer species (B. pendula, B. pubescens, and A. incana were most common) increases, forming canopy gaps. These might provide access to more resources for understory trees, 
decreasing their mortality, hence, probably explaining the thrice lower volume of coniferous CWD in old-growth stands than that in mature stands.

Various deadwood species supply substrates of different chemical compositions, as well as provide a more diverse layout of debris poses, as a share of standing trees and snags and lying deadwood is species-specific [54]. We found about $60 \%$ to $85 \%$ of CWD lying, similarly to findings of aspen deadwood in old-growth coniferous-dominated forests: $60 \%$ to $75 \%[8,9]$. Aspen typically tends to snap, forming both broken snags and lying deadwood $[54,69]$. Stems of low density are more fragile to breakage $[70,71]$, and aspen stems are characteristic of crumbling into pieces when a tree falls, possibly leading to underestimation of aspen CWD if the broken pieces are shorter than the minimum measured length of a particular study. Additionally, smaller (shorter) debris has a larger proportion of surface area exposed to decomposer colonization and a higher degree of soil contact that increases moisture of the deadwood [70]. Both of these factors contribute to an increased deadwood turnover rate for smaller debris. Besides the size, deadwood pose largely affects substrate conditions, with dry snags and leaning logs being a less suitable substrate for wood-decaying fungi compared to moist deadwood [18,72], thus prolonging deadwood's life span [10,73].

Our estimated CWD volume in the old-growth stands was affected by gradual decay. This should most certainly apply to aspen, as it is among the species with a relatively fast turnover rate, with $85 \%$ of the initial mass lost in 27 years for logs $5-25 \mathrm{~cm}, 43$ years for logs 25-60 cm, and 106 years for bark [74]. Another study has suggested a much longer aspen decomposition time, 110 to 120 years [10]. Still, aspen has the strongest loss of wood density during decomposition also if compared with other short-lived species, i.e., birch [10,39] and black alder [39].

Softwood CWD has a longer turnover time than hardwoods [10]. Although no distinction between the softwood species was made, it should predominantly consist of spruce, as pine rarely occurred in the studied stands. For spruce in unmanaged boreal forests, deadwood half-lives varied from 12 to 27 years for standing snags and from 20 to 40 years for lying debris [52]. Relatively rapid decomposition for spruce was also reported in the boreal old-growth forest where spruce at the last decay stage was estimated to be dead for 34 years [75]. A longer half-life duration was found for softwood snags in forests across Switzerland, about 45 to 48 years [76].

Considering the decomposition times, the old-growth stands could comprise some legacy deadwood in the last decay classes that have originated from the previous (predisturbance) generation. Alternatively, deadwood from the previous generation could be omitted in our measurements. That could be if the legacy deadwood appears in the form of buried CWD [77], as only visible debris was measured, including that overgrown by mosses but still forming distinctive appearance from the ground layer. This might lead to underestimation of total deadwood stocks, as well as total carbon stocks, if the buried CWD is not accounted into forest floor carbon estimates..

The overmature stands had low or absent recently dead and weakly decomposed CWD. A similar pattern of CWD availability regarding stand age has been described for $P$. tremuloides [19]. The wood of more decomposed classes was similar for all stand age groups, indicating that overmature stands are at a state of stand development when mortality due to self-thinning has diminished while mortality due to senescence has not become apparent yet. This might be a concern for saproxylic species, as they show a preference for deadwood of a particular decomposition level [78-80].

The spatial availability showed rather regular CWD distribution for all stand age groups, with at least two-thirds of the plots comprising at least $20 \mathrm{~m}^{3} \mathrm{ha}^{-1}$ at all age groups. Our results coincide with an extensive study across Europe by Puletti et al. [81] that showed that $72 \%$ of sample plots comprise deadwood amount up to $25 \mathrm{~m}^{3} \mathrm{ha}^{-1}$. Observations of much higher deadwood volume are often related to damage to living trees [55,82], however, stands with signs of notable damage to living trees were omitted in the selection of our study areas. 
Deadwood is also an important carbon pool that partly acts as a carbon source to the atmosphere and partly redistributes carbon to soil [83,84]. The vast heterogeneity of deadwood (e.g., tree species, type, size, pose, level of decay) that determine the richness of saproxylic organisms $[67,85]$ makes it complicated to assess carbon storage within it. For aspen, controversial findings of its carbon concentration throughout proceeding decomposition have been reported claiming no effect [20], reduced [39,86], or increased [87] carbon concentration along the decay stages. Precise calculations are also hampered by species-specific features related to characteristic decay from inside of living trees that complicate both live and dead aspen wood estimations.

Aspen is susceptible to heart rot infection caused by Phellinus tremulae (Bond.) Bond. and Borisov [88,89]. Infected aspen trees are found through all stand development stages, including these younger than 40 years. Trees severely infected while alive have a faster transition through decay classes after death [90]. This, on the one hand, hinders the assessment of total deadwood volume due to part of already-dead wood still enclosed or attached to living trees. On the other hand, mature aspen stems are commonly hollowed by heart rot $[9,50]$, leading to overestimated deadwood volume if the hollow of the dead stem is not excluded from deadwood estimates.

Forest restructuration by senescence among dominant trees or disturbances alters stand carbon balance with reduced photosynthesis and increased heterotrophic respiration. There are various mutually non-exclusive hypotheses for stand biomass dynamics with respect to carbon pathways along stand succession [91]. Whether old-growth forests continue to accumulate, decline, or stabilize carbon balance, largely depends on stand development after early succession [34]. Small-scale disturbances could have a minor effect on ecosystem production, as forests shifting from early- to late-successional species remained stable ecosystem production regardless of increased heterotrophic respiration from enlarged deadwood volume [92]. However, debris, as discussed above, persists as a $\mathrm{CO}_{2}$ source over several decades, af-fecting the net carbon balance of the stand [26], especially for aspen with a relatively fast decomposition rate $[10,74]$. Thus, alternatively, even with relatively small patches of increased deadwood volume (increased net emissions), gradual changes in species composition could switch forests from a carbon sink to a source of $\mathrm{CO}_{2}$ to the at-mosphere [26]. A study that focused on multiple succession pathways in old boreal forests found a decline in total ecosystem carbon pool from transition to late-succession stages irrespective of tree species combinations [34]. All these relations, however, might be inter-rupted by unpreventable stand-replacing disturbances that cause old, carbon-saturated forests to release large amounts of carbon into the atmosphere $[93,94]$. This might also af-fect forest landscapes as the disturbance regimes are changing with climate change [95].

\section{Conclusions}

There was a large CWD volume in both managed and unmanaged stands. The CWD profile was diverse in species composition and layout of debris poses. Substantial CWD volume was comprised of large diameter units and was frequently found in the studied stands. Our estimated CWD volume and CWD carbon pool represent rather maximum mean quantities regarding the high probability of decayed heartwood or hollowed trees (assessment not included in this paper) in aspen stands that have reached maturity. Considering stand age, changes in CWD species composition together with the high volume of recently dead debris suggests early senescence of dominant aspen cohort in old-growth stands. Further monitoring studies would render the understanding of stand development pathway through dominant pioneer species substitution, regarding CWD carbon pool and CWD dynamics for a relatively short-lived tree species. 
Author Contributions: Conceptualization, Ā.J., I.J., and G.Š.; methodology, G.Š. and S.̌̌.; formal analysis, G.Š., K.B., and I.J.; data curation, I.S. and I.J.; writing-original draft preparation, S.Š and I.J.; writing-review and editing, G.Š., Ā.J., and L.L.; project administration, Ā.J. All authors have read and agreed to the published version of the manuscript.

Funding: This research was funded by the LVM project "Carbon cycle in forest ecosystem".

Data Availability Statement: Not applicable.

Conflicts of Interest: The authors declare no conflict of interest.

\section{References}

1. Caudullo, G.; de Rigo, D. Populus tremula in Europe: Distribution, habitat, usage and threats. In European Atlas of Forest Tree Species; San-Miguel-Ayanz, J., de Rigo, D., Caudullo, G., Houston Durrant, T., Mauri, A., Eds.; Publication Office of the European Union: Luxembourg, 2016; pp. 138-139.

2. Heräjärvi, H.; Junkkonen, R. Wood density and growth rate of European and hybrid aspen in Southern Finland. Balt. For. 2006, $12,2-8$.

3. Global Forest Resources Assessment. Country Report, Sweden; Global Forest Resources Assessment: Rome, Italy, 2015.

4. Rogers, P.C.; Pinno, B.D.; Šebesta, J.; Albrectsen, B.R.; Li, G.; Ivanova, N.; Kusbach, A.; Kuuluvainen, T.; Landhäusser, S.M.; Liu, H.; et al. A global view of aspen: Conservation science for widespread keystone systems. Glob. Ecol. Conserv. 2020, 21 , e00828. [CrossRef]

5. Sverdrup-Thygeson, A.; Ims, R.A. The effect of forest clearcutting in Norway on the community of saproxylic beetles on aspen. Biol. Conserv. 2002, 106, 347-357. [CrossRef]

6. Kouki, J.; Arnold, K.; Martikainen, P. Long-term persistence of aspen-A key host for many threatened species-Is endangered in old-growth conservation areas in Finland. J. Nat. Conserv. 2004, 12, 41-52. [CrossRef]

7. Kivinen, S.; Koivisto, E.; Keski-Saari, S.; Poikolainen, L.; Tanhuanpää, T.; Kuzmin, A.; Viinikka, A.; Heikkinen, R.K.; Pykälä, J.; Virkkala, R.; et al. A keystone species, European aspen (Populus tremula L.), in boreal forests: Ecological role, knowledge needs and mapping using remote sensing. For. Ecol. Manag. 2020, 462, 118008. [CrossRef]

8. Siitonen, J.; Martikainen, P.; Punttila, P.; Rauh, J. Coarse woody debris and stand characteristics in mature managed and old-growth boreal mesic forests in southern Finland. For. Ecol. Manag. 2000, 128, 211-225. [CrossRef]

9. Latva-Karjanmaa, T.; Penttilä, R.; Siitonen, J. The demographic structure of European aspen (Populus tremula) populations in managed and old-growth boreal forests in eastern Finland. Can. J. For. Res. 2007, 37, 1070-1081. [CrossRef]

10. Shorohova, E.; Kapitsa, E. Influence of the substrate and ecosystem attributes on the decomposition rates of coarse woody debris in European boreal forests. For. Ecol. Manag. 2014, 315, 173-184. [CrossRef]

11. Halme, P.; Purhonen, J.; Marjakangas, E.L.; Komonen, A.; Juutilainen, K.; Abrego, N. Dead wood profile of a semi-natural boreal forest-implications for sampling. Silva Fenn. 2019, 53, 10010. [CrossRef]

12. Laarmann, D.; Korjus, H.; Sims, A.; Stanturf, J.A.; Kiviste, A.; Köster, K. Analysis of forest naturalness and tree mortality patterns in Estonia. For. Ecol. Manag. 2009, 258, S187-S195. [CrossRef]

13. Doerfler, I.; Gossner, M.M.; Müller, J.; Seibold, S.; Weisser, W.W. Deadwood enrichment combining integrative and segregative conservation elements enhances biodiversity of multiple taxa in managed forests. Biol. Conserv. 2018, 228, 70-78. [CrossRef]

14. Koivula, M.; Vanha-Majamaa, I. Experimental evidence on biodiversity impacts of variable retention forestry, prescribed burning, and deadwood manipulation in Fennoscandia. Ecol. Process. 2020, 9, 1-22. [CrossRef]

15. Covey, K.R.; Bueno de Mesquita, C.; Oberle, B.; Maynard, D.S.; Bettigole, C.; Crowther, T.W.; Duguid, M.C.; Steven, B.; Zanne, A.E.; Lapin, M.; et al. Greenhouse trace gases in deadwood. Biogeochemistry 2016, 130, 215-226. [CrossRef]

16. Pan, Y.; Birdsey, R.A.; Fang, J.; Houghton, R.; Kauppi, P.E.; Kurz, W.A.; Phillips, O.L.; Shvidenko, A.; Lewis, S.L.; Canadell, J.G.; et al. A large and persistent carbon sink in the world's forests. Science 2011, 333, 988-993. [CrossRef]

17. Ranius, T.; Kindvall, O.; Kruys, N.; Jonsson, B.G. Modelling dead wood in Norway spruce stands subject to different management regimes. For. Ecol. Manag. 2003, 182, 13-29. [CrossRef]

18. Cornelissen, J.H.C.; Sass-Klaassen, U.; Poorter, L.; Van Geffen, K.; Van Logtestijn, R.S.P.; Van Hal, J.; Goudzwaard, L.; Sterck, F.J.; Klaassen, R.K.W.M.; Freschet, G.T.; et al. Controls on coarse wood decay in temperate tree species: Birth of the LOGLIFE experiment. Ambio 2012, 41, 231-245. [CrossRef]

19. Garbarino, M.; Marzano, R.; Shaw, J.D.; Long, J.N. Environmental drivers of deadwood dynamics in woodlands and forests. Ecosphere 2015, 6, 30. [CrossRef]

20. Martin, A.; Dimke, G.; Doraisami, M.; Thomas, S. Carbon fractions in the world's dead wood. Nat. Commun. 2021, 12, 889. [CrossRef]

21. Carey, E.V.; Sala, A.; Keane, R.; Callaway, R.M. Are old forests underestimated as global carbon sinks? Glob. Chang. Biol. 2001, 7, 339-344. [CrossRef]

22. Röser, C.; Montagnani, L.; Schulze, E.-D.; Mollicone, D.; Kolle, O.; Meroni, M.; Papale, D.; Marchesini, L.B.; Federici, S.; Valentini, R. Net $\mathrm{CO}_{2}$ exchange rates in three different successional stages of the "Dark Taiga" of central Siberia. Tellus B Chem. Phys. Meteorol. 2002, 54, 642-654. [CrossRef] 
23. Wardle, D.A.; Hörnberg, G.; Zackrisson, O.; Kalela-Brundin, M.; Coomes, D.A. Long-term effects of wildfire on ecosystem properties across an island area gradient. Science 2003, 300, 972-975. [CrossRef] [PubMed]

24. Luyssaert, S.; Schulze, E.D.; Börner, A.; Knohl, A.; Hessenmöller, D.; Law, B.E.; Ciais, P.; Grace, J. Old-growth forests as global carbon sinks. Nature 2008, 455, 213-215. [CrossRef]

25. Seedre, M.; Kopáček, J.; Janda, P.; Bače, R.; Svoboda, M. Carbon pools in a montane old-growth Norway spruce ecosystem in Bohemian Forest: Effects of stand age and elevation. For. Ecol. Manag. 2015, 346, 106-113. [CrossRef]

26. Hadden, D.; Grelle, A. Net $\mathrm{CO}_{2}$ emissions from a primary boreo-nemoral forest over a 10 year period. For. Ecol. Manag. 2017, 398, 164-173. [CrossRef]

27. Pukkala, T. Does management improve the carbon balance of forestry? For. Int. J. For. Res. 2017, 90, 125-135. [CrossRef]

28. Nord-Larsen, T.; Vesterdal, L.; Bentsen, N.S.; Larsen, J.B. Ecosystem carbon stocks and their temporal resilience in a semi-natural beech-dominated forest. For. Ecol. Manag. 2019, 447, 67-76. [CrossRef]

29. Uri, V.; Varik, M.; Aosaar, J.; Kanal, A.; Kukumägi, M.; Lõhmus, K. Biomass production and carbon sequestration in a fertile silver birch (Betula pendula Roth) forest chronosequence. For. Ecol. Manag. 2012, 267, 117-126. [CrossRef]

30. Uri, V.; Kukumägi, M.; Aosaar, J.; Varik, M.; Becker, H.; Morozov, G.; Karoles, K. Ecosystems carbon budgets of differently aged downy birch stands growing on well-drained peatlands. For. Ecol. Manag. 2017, 399, 82-93. [CrossRef]

31. Varik, M.; Aosaar, J.; Ostonen, I.; Lõhmus, K.; Uri, V. Carbon and nitrogen accumulation in belowground tree biomass in a chronosequence of silver birch stands. For. Ecol. Manag. 2013, 302, 62-70. [CrossRef]

32. Varik, M.; Kukumägi, M.; Aosaar, J.; Becker, H.; Ostonen, I.; Lõhmus, K.; Uri, V. Carbon budgets in fertile silver birch (Betula pendula Roth) chronosequence stands. Ecol. Eng. 2015, 77, 284-296. [CrossRef]

33. Šēnhofa, S.; Jaunslaviete, I.; Šnepsts, G.; Jansons, J.; Liepa, L.; Jansons, A. Deadwood characteristics in mature and old-growth birch stands and their implications for carbon storage. Forests 2020, 11, 536. [CrossRef]

34. Gao, B.; Taylor, A.R.; Searle, E.B.; Kumar, P.; Ma, Z.; Hume, A.M.; Chen, H.Y.H. Carbon Storage Declines in Old Boreal Forests Irrespective of Succession Pathway. Ecosystems 2017, 21, 1168-1182. [CrossRef]

35. European Environment Agency. European Forest Types. Categories and Types for Sustainable Forest Management Reporting and Policy; Technical Report; European Environment Agency: Copenhagen, Denmark, 2007.

36. Bušs, K. Forest ecosystem classification in Latvia. Proc. Latv. Acad. Sci. Sect. B Nat. Exact Appl. Sci. 1997, 51, 204-218.

37. Buchwald, E. A hierarchical terminology for more or less natural forests in relation to sustainable management and biodiversity conservation. In Proceedings of the Proceedings of the Third Expert Meeting on Harmonizing Forest-related Definitions, Rome, Italy, 11-19 January 2005.

38. Mäkinen, H.; Hynynen, J.; Siitonen, J.; Sievänen, R. Predicting the decomposition of scots pine, norway spruce, and birch stems in Finland. Ecol. Appl. 2006, 16, 1865-1879. [CrossRef]

39. Köster, K.; Metslaid, M.; Engelhart, J.; Köster, E. Dead wood basic density, and the concentration of carbon and nitrogen for main tree species in managed hemiboreal forests. For. Ecol. Manag. 2015, 354, 35-42. [CrossRef]

40. Jansons, J.; Līcīte, I. Latvia. In National Forest Inventories: Pathways for Common Reporting; Tomppo, E., Gschwantner, T., Lawrence, M., McRoberts, R.E., Eds.; Springer: Dordrecht, The Netherlands, 2010; pp. 341-350.

41. Liepa, I. Pieauguma mācība; LLU: Jelgava, Latvia, 1996.

42. Bobiec, A. The influence of gaps on tree regeneration: A case study of the mixed lime-hornbeam (Tilio-Carpinetum Tracz. 1962) communities in the Białowieża Primeval Forest. Polish J. Ecol. 2007, 55, 441-455.

43. Jonášová, M.; Matějková, I. Natural regeneration and vegetation changes in wet spruce forests after natural and artificial disturbances. Can. J. For. Res. 2007, 37, 1907-1914. [CrossRef]

44. Vehmas, M.; Kouki, J.; Eerikainen, K. Long-term spatio-temporal dynamics and historical continuity of European aspen (Populus tremula L.) stands in the Koli National Park, eastern Finland. Forestry 2009, 82, 135-148. [CrossRef]

45. Kull, O.; Niinemets, Ü. Distribution of leaf photosynthetic properties in tree canopies: Comparison of species with different shade tolerance. Funct. Ecol. 1998, 12, 472-479. [CrossRef]

46. Yatskov, M.; Harmon, M.E.; Krankina, O.N. A chronosequence of wood decomposition in the boreal forests of Russia. Can. J. For. Res. 2003, 33, 1211-1226. [CrossRef]

47. Jonsson, B.G.; Ekström, M.; Esseen, P.A.; Grafström, A.; Ståhl, G.; Westerlund, B. Dead wood availability in managed Swedish forests-Policy outcomes and implications for biodiversity. For. Ecol. Manag. 2016, 376, 174-182. [CrossRef]

48. Similä, M.; Kouki, J.; Martikainen, P. Saproxylic beetles in managed and seminatural Scots pine forests: Quality of dead wood matters. For. Ecol. Manag. 2003, 174, 365-381. [CrossRef]

49. Adermann, V. Estonia. In National Forest Inventories: Pathways for Common Reporting; Tomppo, E., Gschwantner, T., Lawrence, M., McRoberts, R.E., Eds.; Springer: Dordrecht, The Netherlands, 2010; pp. 171-184.

50. Siitonen, J. Forest management, coarse woody debris and saproxylic organisms: Fennoscandian boreal forests as an example. Ecol. Bull. 2001, 49, 11-41. [CrossRef]

51. Rouvinen, S.; Kuuluvainen, T.; Karjalainen, L. Coarse woody debris in old Pinus sylvestris dominated forests along a geographic and human impact gradient in boreal Fennoscandia. Can. J. For. Res. 2002, 32, 2184-2200. [CrossRef]

52. Aakala, T. Coarse woody debris in late-successional Picea abies forests in northern Europe: Variability in quantities and models of decay class dynamics. For. Ecol. Manag. 2010, 260, 770-779. [CrossRef]

53. Lee, P. Dynamics of snags in aspen-dominated midboreal forests. For. Ecol. Manag. 1998, 105, 263-272. [CrossRef] 
54. Vasiliauskas, R.; Vasiliauskas, A.; Stenlid, J.; Matelis, A. Dead trees and protected polypores in unmanaged north-temperate forest stands of Lithuania. For. Ecol. Manag. 2004, 193, 355-370. [CrossRef]

55. Bujoczek, L.; Bujoczek, M.; Zięba, S. How much, why and where? Deadwood in forest ecosystems: The case of Poland. Ecol. Indic. 2021, 121, 107027. [CrossRef]

56. Krankina, O.N.; Treyfeld, R.F.; Harmon, M.E.; Spycher, G.; Povarov, E.D. Coarse Woody Debris in the Forests of the St. Petersburg Region, Russia. Ecol. Bull. 2001, 93-107. [CrossRef]

57. Lee, P.C.; Crites, S.; Nietfeld, M.; Nguyen, H.V.; Stelfox, J.B. Characteristics and origins of deadwood material in aspen-dominated boreal forests. Ecol. Appl. 1997, 7, 691-701. [CrossRef]

58. Köster, K.; Jõgiste, K.; Tukia, H.; Niklasson, M.; Möls, T. Variation and ecological characteristics of coarse woody debris in Lahemaa and Karula National Parks, Estonia. Scand. J. For. Res. 2005, 20, 102-111. [CrossRef]

59. Nilsson, S.G.; Niklasson, M.; Hedin, J.; Aronsson, G.; Gutowski, J.M.; Linder, P.; Ljungberg, H.; Mikusinski, G.; Ranius, T. Densities of large living and dead trees in old-growth temperate and boreal forests. For. Ecol. Manag. 2002, 161, 198-204. [CrossRef]

60. Framstad, E.; de Wit, H.; Mäkipää, R.; Larjavaar, M.; Vesterdal, L.; Karltun, E. Biodiversity, Carbon Storage and Dynamics of Old Northern Forests; Nordic Council of Ministers: Copenhagen, Denmark, 2013.

61. Chen, H.Y.H.; Popadiouk, R.V. Dynamics of North American boreal mixedwoods. Environ. Rev. 2002, 10, 137-166. [CrossRef]

62. Liepina, L. Apses. In Meža Enciklopēdija; Broks, J., Ed.; Zelta Grauds: Rīga, Latvia, 2005.

63. Lankia, H.; Wallenius, T.; Várkonyi, G.; Kouki, J.; Snäll, T. Forest fire history, aspen and goat willow in a Fennoscandian old-growth landscape: Are current population structures a legacy of historical fires? J. Veg. Sci. 2012, 23, 1159-1169. [CrossRef]

64. Müller, J.; Bütler, R. A review of habitat thresholds for dead wood: A baseline for management recommendations in European forests. Eur. J. For. Res. 2010, 129, 981-992. [CrossRef]

65. Brin, A.; Brustel, H.; Jactel, H. Species variables or environmental variables as indicators of forest biodiversity: A case study using saproxylic beetles in Maritime pine plantations. Ann. For. Sci. 2009, 66, 306. [CrossRef]

66. Hottola, J.; Ovaskainen, O.; Hanski, I. A unified measure of the number, volume and diversity of dead trees and the response of fungal communities. J. Ecol. 2009, 97, 1320-1328. [CrossRef]

67. Lassauce, A.; Paillet, Y.; Jactel, H.; Bouget, C. Deadwood as a surrogate for forest biodiversity: Meta-analysis of correlations between deadwood volume and species richness of saproxylic organisms. Ecol. Indic. 2011, 11, 1027-1039. [CrossRef]

68. Hekkala, A.M.; Ahtikoski, A.; Päätalo, M.L.; Tarvainen, O.; Siipilehto, J.; Tolvanen, A. Restoring volume, diversity and continuity of deadwood in boreal forests. Biodivers. Conserv. 2016, 25, 1107-1132. [CrossRef]

69. Liu, Q.; Hytteborn, H. Gap structure, disturbance and regeneration in a primeval Picea abies forest. J. Veg. Sci. 1991, 2, 391-402. [CrossRef]

70. Cornwell, W.K.; Cornelissen, J.H.C.; Allison, S.D.; Bauhus, J.; Eggleton, P.; Preston, C.M.; Scarff, F.; Weedon, J.T.; Wirth, C.; Zanne, A.E. Plant traits and wood fates across the globe: Rotted, burned, or consumed? Glob. Chang. Biol. 2009, 15, 2431-2449. [CrossRef]

71. Niklas, K.J.; Spatz, H.-C. Worldwide correlations of mechanical properties and green wood density. Am. J. Bot. 2010, 97, 1587-1594 [CrossRef]

72. Jacobsen, R.M.; Sverdrup-Thygeson, A.; Kauserud, H.; Mundra, S.; Birkemoe, T. Exclusion of invertebrates influences saprotrophic fungal community and wood decay rate in an experimental field study. Funct. Ecol. 2018, 32, 2571-2582. [CrossRef]

73. DeLong, S.C.; Daniels, L.D.; Heemskerk, B.; Storaunet, K.O. Temporal development of decaying log habitats in wet spruce-fir stands in east-central British Columbia. Can. J. For. Res. 2005, 35, 2841-2850. [CrossRef]

74. Tarasov, M.E.; Birdsey, R.A. Decay rate and potential storage of coarse woody debris in the Leningrad region. Ecol. Bull. 2001, 137-147. [CrossRef]

75. Jonsson, B.G. Availability of coarse woody debris in a boreal old-growth Picea abies forest. J. Veg. Sci. 2000, 11, 51-56. [CrossRef]

76. Hararuk, O.; Kurz, W.A.; Didion, M. Dynamics of dead wood decay in Swiss forests. For. Ecosyst. 2020, 7, 36. [CrossRef]

77. Moroni, M.T.; Morris, D.M.; Shaw, C.; Stokland, J.N.; Harmon, M.E.; Fenton, N.J.; Merganičová, K.; Merganič, J.; Okabe, K.; Hagemann, U. Buried Wood: A Common Yet Poorly Documented Form of Deadwood. Ecosystems 2015, 18, 605-628. [CrossRef]

78. Tikkanen, O.-P.; Martikainen, P.; Hyvärinen, E.; Junninen, K.; Kouki, J. Red-listed boreal forest species of Finland: Associations with forest structure, tree species, and decaying wood. Ann. Zool. Fennici 2006, 43, 373-383. [CrossRef]

79. Ranius, T.; Martikainen, P.; Kouki, J. Colonisation of ephemeral forest habitats by specialised species: Beetles and bugs associated with recently dead aspen wood. Biodivers. Conserv. 2011, 20, 2903-2915. [CrossRef]

80. Shorohova, E.; Kushnevskaya, H.; Ruokolainen, A.; Polevoi, A.; Borovichev, E. Behavior in a wide range of choices: Substrate preferences of threatened wood-inhabiting species in a mixed old-growth boreal forest. In Proceedings of the ECCB2018 5th European Congress of Conservation Biology, Jyväskylä, Finland, 12-15 June 2018; Open Science Centre, University of Jyväskylä: Jyväskylä, Finland, 2018.

81. Puletti, N.; Canullo, R.; Mattioli, W.; Gawryś, R.; Corona, P.; Czerepko, J. A dataset of forest volume deadwood estimates for Europe. Ann. For. Sci. 2019, 76, 1-8. [CrossRef]

82. Priewasser, K.; Brang, P.; Bachofen, H.; Bugmann, H.; Wohlgemuth, T. Impacts of salvage-logging on the status of deadwood after windthrow in Swiss forests. Eur. J. For. Res. 2013, 132, 231-240. [CrossRef]

83. Kahl, T.; Baber, K.; Otto, P.; Wirth, C.; Bauhus, J. Drivers of $\mathrm{CO}_{2}$ Emission Rates from Dead Wood Logs of 13 Tree Species in the Initial Decomposition Phase. Forests 2015, 6, 2484-2504. [CrossRef] 
84. Błońska, E.; Lasota, J.; Tullus, A.; Lutter, R.; Ostonen, I. Impact of deadwood decomposition on soil organic carbon sequestration in Estonian and Polish forests. Ann. For. Sci. 2019, 76, 1-14. [CrossRef]

85. Seibold, S.; Bässler, C.; Brandl, R.; Büche, B.; Szallies, A.; Thorn, S.; Ulyshen, M.D.; Müller, J. Microclimate and habitat heterogeneity as the major drivers of beetle diversity in dead wood. J. Appl. Ecol. 2016, 53, 934-943. [CrossRef]

86. Kēnina, L.; Mača, S.; Jaunslaviete, I.; Jansons, Ā. Carbon pools in old-growth Scots pine stands on organic soils and its concentration in deadwood: Cases study in Latvia. In Proceedings of the 9th International Scientific Conference "Rural Development 2019", Kaunas, Lithuania, 26-28 September; VDU: Kaunas, Lithuania, 2019; pp. 284-288.

87. Stakènas, V.; Varnagirytė-Kabašinskienè, I.; Sirgedaitė-Šěžienè, V.; Armolaitis, K.; Araminienè, V.; Muraškienè, M.; Žemaitis, P. Dead wood carbon density for the main tree species in the Lithuanian hemiboreal forest. Eur. J. For. Res. 2020, 139, 1045-1055. [CrossRef]

88. Witt, C. Characteristics of aspen infected with heartrot: Implications for cavity-nesting birds. For. Ecol. Manag. 2010, 260, 1010-1016. [CrossRef]

89. Lõhmus, A. Aspen-inhabiting aphyllophoroid fungi in a managed forest landscape in Estonia. Scand. J. For. Res. 2011, 26, 212-220. [CrossRef]

90. Andelic, M.; Tangnaes, M.-J. The Effect of Secondary Metabolites, Nutrients and Invertebrates on Fungal Establishment and Decomposition Rates in European Aspen (Populus tremula). Master's Thesis, Norwegian University of Life Sciences, Ås, Norway, 2019.

91. Wirth, C.; Lichstein, J.W. The Imprint of Species Turnover on Old-Growth Forest Carbon Balances-Insights From a Trait-Based Model of Forest Dynamics; Springer: Berlin/Heidelberg, Germany, 2009; pp. 81-113.

92. Schmid, A.V.; Vogel, C.S.; Liebman, E.; Curtis, P.S.; Gough, C.M. Coarse woody debris and the carbon balance of a moderately disturbed forest. For. Ecol. Manag. 2016, 361, 38-45. [CrossRef]

93. Harmon, M.E.; Bond-Lamberty, B.; Tang, J.; Vargas, R. Heterotrophic respiration in disturbed forests: A review with examples from North America. J. Geophys. Res. Biogeosci. 2011, 116, G00K04. [CrossRef]

94. Nabuurs, G.J.; Lindner, M.; Verkerk, P.J.; Gunia, K.; Deda, P.; Michalak, R.; Grassi, G. First signs of carbon sink saturation in European forest biomass. Nat. Clim. Chang. 2013, 3, 792-796. [CrossRef]

95. Senf, C.; Seidl, R. Mapping the forest disturbance regimes of Europe. Nat. Sustain. 2021, 4, 63-70. [CrossRef] 